\title{
An Investigation Of Investors' Use Of Reported Cash Flow And Accrual Information For Eight Countries
}

Joan Hollister, (E-mail: hollistj@newpaltz.edu), State University of New York, New Paltz Victoria Shoaf, (E-mail: shoafv@stjohns.edu), St. John’s University

\begin{abstract}
Using 1995 through 1999 data from the United States and seven other countries with different sets of national accounting standards (Canada, France, Germany, Hong Kong, Japan, Malaysia, and the United Kingdom), we test whether the cash flow component of earnings is more persistent than the accrual component, and then whether the relative persistence of these two earnings components is reflected in stock market returns. Using the Mishkin model employed by Sloan (1996) to test the data for each of the countries, we find that, while reported cash flows are significantly more persistent than accruals in each of the eight accounting regimes, Canadian companies are the only ones for which the pricing of equity securities is clearly efficient with regard to cash flow and accrual information. While there is some evidence for this stock market efficiency for the UK and German companies, it is not conclusive. For firms from France, Hong Kong, Japan, Malaysia, and the United States, the differences observed between the persistence of cash flows and accruals are not reflected in stock prices.
\end{abstract}

\section{INTRODUCTION}

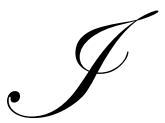

$\mathrm{n}$ its Statement of Financial Accounting Concepts No. 1, the Financial Accounting Standards Board (FASB) stated that reported earnings based on accrual accounting provides financial statement users with important information that is not conveyed by cash flows. Indeed, accounting research, beginning with Ball and Brown (1968), has demonstrated repeatedly that United States (US) stock market valuations are associated with reported accounting earnings. The same conceptual basis was adopted by the International Accounting Standards Committee (IASC) and is reflected in International Accounting Standard No. 1 (which was re-issued in July, 1998, and was adopted by the new International Accounting Standards Board in 2001). The "core" International Accounting Standards (IASs) were accepted by the International Organization of Securities Commissions (IOSCO) in May, 2000, as the basis for cross-border filings of registration statements and listings on securities exchanges.

In finance, on the other hand, it is generally accepted that market forces establish stock prices equal to the discounted expected future cash flows (e.g., Brigham, Gapenski, and Ehrhardt, 1999). This view, combined with some notable business failures due to inadequate cash flows, has led some analysts and other investors to believe that cash flows are more important than total reported accounting earnings and that the accrual component of the earnings figure is accounting fiction. Despite the prevalence of this belief, research has documented that annual cash flows to US businesses do not have the same strength of association with stock returns as do total earnings (Dechow, 1994; Bartov, Goldberg, and Kim, 1997). The conclusion of this research is that both the cash flow and the accrual components are needed to provide full information concerning operating performance.

A separate cash flow statement has been required in US financial reporting since 1987. The FASB concluded in SFAS 95, The Statement of Cash Flows, that reporting cash flows would provide investors with additional information that would be useful in predicting the amounts, timing, and uncertainty of future cash flows. The cash flow statement is also required in the "core" standards issued by the IASC. While it is still not required by 
some national standards setters (e.g., France, where it is only recommended), many countries have adopted a requirement for cash flow reporting in recent years (including Japan, in 2000).

In this project, we investigate whether stock market investors in various countries use the reported cash flows appropriately in their investment decisions. When cash flow information is not reported directly, expertise, time, and energy are necessary to estimate the cash flow component of earnings, if it is to be used. This constraint presents an opportunity for market "inefficiency" with regard to the compounding of information which could be gleaned by separating the reported earnings into the two components, cash flows and accruals. Therefore, we use only reported cash flows, whether required by local standards or provided voluntarily. We first assess whether the cash flow component of earnings is significantly more persistent than the accrual (or non-cash flow) component. We then use the Mishkin model (Mishkin 1983) to test both whether stock market pricing is efficient with regard to the predictive value of total reported earnings and whether the market impounds the relative persistence of the cash flow and accrual components.

Countries' national accounting systems differ for various reasons. In cultures where financing is primarily creditor-based, there has been less pressure to have accounting standards that result in transparent financial statements. The American Accounting Association's morphology for comparative accounting systems (American Accounting Association, 1977) categorizes financial reporting in the UK, the US, and Canada as more representative of the "microeconomic" end of the micro-macro continuum, since emphasis is placed on reporting for investment decisions. Countries such as Germany, France, and Japan have features consistent with a "macroeconomic" basis because their accounting standards are formulated according to national economic policy objectives and because their reporting is intended to serve the needs of multiple stakeholders. When total reported accounting earnings are essentially the same as federally legislated taxable income (as they are, for instance, in Germany and Japan), the reported accounting numbers may not provide as much information to investors as would be provided by the numbers calculated according to standards designed by accounting professionals who are attempting to provide a "fair and true" estimate of a firm's results of operations (as in Canada, the UK, and the US). Since differences in national accounting standards can lead to differences in the relative persistence of the cash flow and accrual components of earnings, we test US companies and companies from seven other countries that have different sets of national accounting standards from the US: Canada, France, Germany, Hong Kong, Japan, Malaysia, and the United Kingdom.

\section{DEVELOPMENT OF HYPOTHESES}

We first investigate whether the persistence of the cash flow component of earnings differs from the persistence of the accrual component. That is, we determine the relative weights of the cash flow and accrual components of earnings by regressing total earnings on the two components; these relative weights would presumably then be used in predicting the following year's earnings if they are persistent. Over time, accounting researchers have developed sophisticated earnings expectations models (e. g., time-series or ARIMA models, described in Beaver, 1970; Ball and Watts, 1972; Watts and Leftwich, 1977; etc.), and there is evidence that analysts' forecasts provide the most accurate earnings expectations. However, the results of Bernard and Thomas (1989) indicate that investors' expectations of earnings probably more closely resemble a simple random walk, which is represented by the martingale model,

$$
E\left(X_{i t}\right)=X_{i, t-1}
$$

where expected earnings $(\boldsymbol{X})$ this period are equal to actual earnings from last period. In this formulation, unexpected earnings are equivalent to any change in earnings from last period to this period.

We use this theoretical framework to assess whether cash flow and accrual information are significant predictors of the next year's earnings by disaggregating earnings into the two components, as

$$
E\left(X_{i t}\right)=C F_{i, t-1}+N C F_{i, t-1}
$$

where expected earnings $(\boldsymbol{X})$ this period are equal to the cash flow $(\boldsymbol{C F})$ and non-cash flow $(\boldsymbol{N C F})$ or accrual components of actual earnings from last period. 
We use the phrase "earnings persistence" as Sloan (1996) does, to refer to the relationship between earnings (or a component of earnings) of one year and earnings of the next year. Sloan (1996) demonstrated the greater persistence of the cash flow component of earnings for US companies. For his study, Sloan estimated unreported cash flows for US firms from 1960 through 1991 by eliminating items from net income that could be determined to arise from accruals. We use reported cash flows from operating activities as the cash flow component of earnings, and we expect that it will have greater persistence than the accrual component for all of the countries that we study. When accounting earnings are divided into two parts, cash flows and all of the non-cash flow adjustments, it is the non-cash flow, or accrual, portion that theoretically should be affected by differences in accounting standards. The persistence of the accrual component may therefore vary by country, depending on the accounting standards. Still, while the relative valuation of the accrual component may differ across the countries, we expect it to be consistently lower than the cash flow component. Our first hypothesis, to be tested independently for each country, is:

$\mathbf{H}_{\mathfrak{l}}$ : For year to year prediction, the cash flow component of earnings is weighted more heavily than the accrual component.

After establishing the relationship between the cash flow and accrual components in predicting the next year's earnings, we test market efficiency with regard to its use of total earnings and then with regard to the relative persistence of cash flow and accrual information. Ball and Brown (1968) show that 85-90\% of the information contained in earnings is compounded in stock prices prior to earnings announcements. Building on this empirical phenomenon, rather than a formal economic model, subsequent research often uses the mapping of annual returns onto annual earnings, in the relationship

$$
R_{i t}=\alpha+\beta E_{i t}+\varepsilon_{i t}
$$

where $\boldsymbol{R}$ is the return, $\boldsymbol{E}$ is earnings, $i$ is the firm, $t$ is the period over which results are accumulated, and $\square_{i t}$ is the disturbance term. The parameter $\square$ is known as the earnings-response coefficient, representing the rate at which earnings are reflected in stock prices. This relationship has also been respecified in order to consider only the relation between abnormal returns and unexpected earnings, as

$$
A R_{i t}=a+\beta U E_{i t}+\varepsilon_{i t}
$$

where $\boldsymbol{A} \boldsymbol{R}$ is the abnormal return and $\boldsymbol{U} \boldsymbol{E}$ is unexpected earnings (e.g., as used by Beaver, Lambert, and Morse, 1980; Collins and Kothari, 1989).

If investors use reported total earnings to predict future earnings, as the literature suggests, then we would expect earnings persistence information to be reflected in the stock returns of efficient markets. Our second hypothesis, again to be tested independently for each country, is:

$\mathbf{H}_{2}$ : Stock market prices reflect investors' use of reported total earnings information in predicting future earnings.

Using the model expressed in equation [4] and the earnings expectation established in the first part of the study, we consider the difference between the prediction of next year's earnings and the actual earnings as unexpected, as in the equation,

$$
U E_{i t}=X_{i t}-E\left(X_{i t}\right)
$$

or, substituting the definition of expected earnings in equation [2],

$$
U E_{i t}=X_{i t}-\left(C F_{i, t-1}+N C F_{i, t-1}\right)
$$

where unexpected earnings $(\boldsymbol{U E})$ this period are equal to the actual earnings this period $(\boldsymbol{X})$ less the expected earnings $\boldsymbol{E}(\boldsymbol{X})$, defined as the cash flow $(\boldsymbol{C F})$ and non-cash flow $(\boldsymbol{N C F})$ or accrual components of actual earnings from last period. 
If investors use the information in reported cash flow statements, then we would expect the relative persistence of cash flows and accruals to be reflected in stock market returns. Our third hypothesis, to be tested independently for each country, is:

$\mathbf{H}_{3}$ : Stock market prices reflect investors' use of the demonstrated relative weighting of the cash flow and accrual components of earnings in predicting future earnings.

While research using US annual data has revealed significant associations between returns and accruals (e.g., Rayburn, 1986; Ali, 1994), Sloan (1996) documented that US market pricing did not adequately account for the differences in persistence of the cash flow and the accrual components of accounting earnings. However, most of Sloan's cash flow data was calculated rather than reported. The availability of cash flow information due to the direct reporting of cash flows from operations could, theoretically, have improved capital market use of cash flow data. Since cash flows should not be affected by varying accounting standards, but the accrual component of earnings is country dependent, there should be country-specific differences in the earnings expectations embedded in stock prices with respect to the relative earnings persistence attributable to the cash flow and the accrual components of earnings.

\section{TESTS AND RESULTS}

Our tests are based on the methodology employed by Sloan (1996). We first regress each year's earnings on the previous year's earnings to establish a benchmark for the martingale model, as described in equation [1],

$$
X_{i t}=\alpha+\beta X_{i, t-1}+\varepsilon_{i t}
$$

where $\boldsymbol{X}$ is earnings scaled by average total assets, $i$ is the firm, $t$ is the year, and $\square_{i t}$ is the disturbance term. Then, to test whether the cash flow component is more important than the accrual component of earnings in predicting next year's earnings $\left(\mathrm{H}_{1}\right)$, we follow Sloan in regressing each year's earnings on the previous year's accruals and cash flows. We use the relationship described in equation [2]:

$$
X_{i t}=\alpha+\beta_{1} C F_{i, t-1}+\beta_{2} N C F_{i, t-1}+\varepsilon_{i t}
$$

where $\boldsymbol{C F}$ is the cash flow and $\boldsymbol{N C F}$ is the non-cash flow (accrual) from last period, both scaled by average total assets.

The sample is drawn from the Disclosure Global Researcher Worldscope CD-roms, dated May 2000 and June 2001. Financial reports filed through 1998 and 1999, respectively, are included in these versions of the database. We selected our sample from the years 1995 through 1999. In 1995, many firms outside the US adopted the IASC's recommendation for presenting a cash flow statement, whether or not it was locally required, so starting at this year provided a larger number of firms reporting cash flows than was available in previous years. Still, for some countries (such as Japan), a majority of the observations in the database were deleted because the firms did not report cash flows. We used data as reported in the local currency on local exchanges using local or international accounting standards; non-US firms following US GAAP were eliminated. We selected firms classified as manufacturing, retail, service, and transportation, omitting financial service institutions. For each country, for each year, we trimmed observations for which the stock return was more than four times the standard deviation from the mean. In all cases, except for the US in 1995, the number of observations eliminated was less than $1 \%$ of the observations for which all of the required data was available. 
Table 1

Earnings Regressed on Prior Year's Earnings and on the Cash Flow and Accrual Components of Prior Year's Earnings

Basic model: $X_{i t}=\alpha+\beta X_{i, t-1}+\varepsilon_{i t} \quad$ Disaggregated Model: $X_{i t}=a+\beta_{1} C F_{i, t-1}+\beta_{2} N C F_{i, t-1}+\varepsilon_{i t}$

Panel A:

Panel B:

\begin{tabular}{|c|c|c|c|c|c|c|c|c|}
\hline Country & $\alpha$ & $\beta$ & Adj. $R^{2}$ & $\alpha$ & $\beta_{1}$ & $\beta_{2}$ & Adj. $R^{2}$ & $\beta_{1}=\beta_{2}$ \\
\hline $\begin{array}{c}\text { Canada } \\
(\mathrm{N}=1,655)\end{array}$ & $\begin{array}{l}-.0077 \\
(.02)^{*}\end{array}$ & $\begin{array}{c}.6648 \\
(.00)^{* *}\end{array}$ & .3338 & $\begin{array}{l}-.0253 \\
(.00)^{* *}\end{array}$ & $\begin{array}{l}.7916 \\
(.00)^{* *}\end{array}$ & $\begin{array}{c}.5377 \\
(.00)^{* *}\end{array}$ & .3603 & $\begin{array}{r}X^{2}=69.62 \\
(.000)^{* *}\end{array}$ \\
\hline $\begin{array}{c}\text { France } \\
(\mathrm{N}=767)\end{array}$ & $\begin{array}{l}.0044 \\
(.05)^{*}\end{array}$ & $\begin{array}{c}.7092 \\
(.00)^{* *}\end{array}$ & .5093 & $\begin{array}{c}-.0006 \\
(.81)\end{array}$ & $\begin{array}{l}.7296 \\
(.00)^{* *}\end{array}$ & $\begin{array}{c}.6260 \\
(.00)^{* *}\end{array}$ & .5188 & $\begin{array}{r}\chi^{2}=16.11 \\
(.000)^{* *}\end{array}$ \\
\hline $\begin{array}{l}\text { Germany } \\
(\mathrm{N}=791)\end{array}$ & $\begin{array}{c}.0075 \\
(.00)^{* *}\end{array}$ & $\begin{array}{c}.6679 \\
(.00)^{* *}\end{array}$ & .3011 & $\begin{array}{l}.0012 \\
(.62)\end{array}$ & $\begin{array}{l}.6996 \\
(.00)^{* *}\end{array}$ & $\begin{array}{l}.5878 \\
(.00)^{* *}\end{array}$ & .3292 & $\begin{array}{c}\chi^{2}=34.09 \\
(.000)^{* * *}\end{array}$ \\
\hline $\begin{array}{l}\text { Hong Kong } \\
(\mathrm{N}=960)\end{array}$ & $\begin{array}{l}-.0129 \\
(.02)^{*}\end{array}$ & $\begin{array}{c}.5454 \\
(.00)^{* *}\end{array}$ & .2035 & $\begin{array}{l}-.0360 \\
(.00)^{* *}\end{array}$ & $\begin{array}{l}.8365 \\
(.00)^{* *}\end{array}$ & $\begin{array}{c}.4323 \\
(.00)^{* *}\end{array}$ & .2589 & $\begin{array}{r}\chi^{2}=72.72 \\
(.000)^{* *}\end{array}$ \\
\hline $\begin{array}{c}\text { Japan } \\
(\mathrm{N}=1,373)\end{array}$ & $\begin{array}{c}.0031 \\
(.00)^{* *}\end{array}$ & $\begin{array}{c}.6946 \\
(.00)^{* *}\end{array}$ & .4102 & $\begin{array}{l}.0007 \\
(.45)\end{array}$ & $\begin{array}{l}.7087 \\
(.00)^{* *}\end{array}$ & $\begin{array}{l}.6496 \\
(.00)^{* *}\end{array}$ & .4189 & $\begin{array}{c}\chi^{2}=21.43 \\
(.000)^{* * *}\end{array}$ \\
\hline $\begin{array}{l}\text { Malaysia } \\
(\mathrm{N}=895)\end{array}$ & $\begin{array}{c}-.0087 \\
(.43)\end{array}$ & $\begin{array}{c}.3685 \\
(.00)^{* *}\end{array}$ & .1271 & $\begin{array}{l}-.0449 \\
(.00)^{* *}\end{array}$ & $\begin{array}{l}.7600 \\
(.00)^{* *}\end{array}$ & $\begin{array}{c}.3047 \\
(.00)^{* *}\end{array}$ & .2109 & $\begin{array}{c}\chi^{2}=95.82 \\
(.000)^{* *}\end{array}$ \\
\hline $\begin{array}{l}\text { United Kingdom } \\
\qquad(\mathrm{N}=5,061)\end{array}$ & $\begin{array}{l}.0063 \\
(.08)^{*}\end{array}$ & $\begin{array}{c}.5426 \\
(.00)^{* *}\end{array}$ & .1594 & $\begin{array}{l}-.0186 \\
(.00)^{* *}\end{array}$ & $\begin{array}{l}.7602 \\
(.00)^{* *}\end{array}$ & $\begin{array}{c}.3494 \\
(.00)^{* *}\end{array}$ & .1972 & $\begin{array}{c}\chi^{2}=238.9 \\
(.000)^{* * *}\end{array}$ \\
\hline $\begin{array}{l}\text { United States } \\
(\mathrm{N}=18,298)\end{array}$ & $\begin{array}{l}-.0185 \\
(.00)^{* *}\end{array}$ & $\begin{array}{c}.6427 \\
(.00)^{* *}\end{array}$ & .4531 & $\begin{array}{l}-.0497 \\
(.00)^{* *}\end{array}$ & $\begin{array}{c}.9367 \\
(.00)^{* *}\end{array}$ & $\begin{array}{l}.2772 \\
(.00)^{* *}\end{array}$ & .5154 & $\begin{array}{l}\chi^{2}=2354 \\
(.000)^{* * *}\end{array}$ \\
\hline
\end{tabular}

$X=$ annual accounting income before extraordinary items and discontinued operations, scaled by average total assets.

$C F=$ cash flows from operating activities reported on the Cash Flow Statement, scaled by average total assets.

$N C F=$ non-cash flows, or accruals, computed as reported annual accounting income before extraordinary items and discontinued operations less cash flows from operating activities reported on the Cash Flow Statement, scaled by average total assets.

$\mathrm{N}=$ the number of observations in each regression.

The OLS $t$-statistics are shown parenthetically.

$* * /(*)$ Indicates significance for $\mathrm{p}$-values $<.01 /(<.10)$.

The results of the initial tests of persistence are shown in Table 1. The coefficients are estimated with the pooled sample of all the firm-year observations for each country for the 1995 through 1999 time period. Panel A shows the benchmark for earnings as a predictor of the next year's earnings. In each country, there is a strong and significant relationship between current earnings and the prior year's earnings. Panel B shows the results of the test of our first hypothesis, whether for year to year prediction, the cash flow component of earnings is more important than the accrual component. For each country, the cash flow and accrual components are significant, and the cash flow component is weighted more heavily (i.e., the coefficient is higher) than the accrual component. In the right column, we provide a Wald test of the statistical equivalency of the two coefficients; in every case, they are significantly different. The results demonstrate that cash flows and accruals are each informative in predicting future earnings and that cash flows are significantly more persistent than accruals in all eight countries studied.

Following Sloan (1996), we then employed the framework developed by Mishkin (1983) to test first whether stock returns are efficient with regard to the use of the persistence of total earnings and then to test whether they reflect the established properties of the accrual and cash flow components of earnings. This framework requires the estimation of simultaneous equations. For the test of market efficiency with regard to total earnings information, the first equation is the same as our benchmark equation [7], and the second equation is abnormal returns regressed on an 
expression of unexpected earnings based on prior year's earnings predictions of current year's earnings, as in equation [5].

The system of two equations shown below is used to test whether the market accurately weights total reported earnings.

$$
\begin{gathered}
X_{i t}=\alpha+\beta X_{i, t-1}+\varepsilon_{i t} \\
A R_{i t}=\beta_{1}\left(X_{i t}-\alpha-\beta_{2} X_{i, t-1}\right)+\mu_{i t}
\end{gathered}
$$

$\boldsymbol{A} \boldsymbol{R}$ is a size-adjusted abnormal return, calculated for each country by year. In each case, observations were ordered by size (measured by market capitalization), and the mean return for each quintile was subtracted from the realized returns. The subsets by year were then aggregated for each country total. Although the intercept term of the forecast $(\boldsymbol{\alpha}$ is held constant between the two equations, the coefficient for the prior year's earnings is allowed to vary from $\boldsymbol{\beta}$ to $\boldsymbol{\beta}_{2}$. We are then able to test whether the abnormal return is based on an accurate weighting of the total earnings variable. If markets have efficiently impounded the prior year's earnings, there should be no significant difference between $\boldsymbol{\beta}$ and $\boldsymbol{\beta}_{2}$.

Table 2

Simultaneous Regression of Earnings on the Prior Year's Earnings and of Abnormal Returns on a Measure of Unexpected Earnings Based on the Difference Between Earnings and Prior Year's Earnings

Models: $\quad X_{\mathrm{it}}=\alpha+\beta \mathrm{X}_{\mathrm{i}, \mathrm{t}-1}+\varepsilon_{\mathrm{it}}$

\begin{tabular}{|c|c|c|c|c|c|c|c|c|}
\hline Country & $\alpha$ & $\overline{\bar{\beta}}$ & Adj. $\mathbf{R}^{2}$ & $\bar{\alpha}$ & 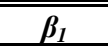 & $\overline{\beta_{2}}$ & Adj. R $^{2}$ & $\bar{\beta}=\beta_{2}$ \\
\hline $\begin{array}{c}\text { Canada } \\
(\mathrm{N}=1,655)\end{array}$ & $\begin{array}{l}-.0075 \\
(.02)^{*}\end{array}$ & $\begin{array}{l}.6646 \\
(.00)^{* *}\end{array}$ & .3338 & $\begin{array}{l}-.0075 \\
(.02)^{*}\end{array}$ & $\begin{array}{l}1.0699 \\
(.00)^{* *}\end{array}$ & $\begin{array}{l}.5705 \\
(.00)^{* *}\end{array}$ & .0634 & $\chi^{2}=1.06$ \\
\hline $\begin{array}{c}\text { France } \\
(\mathrm{N}=767)\end{array}$ & $\begin{array}{l}.0042 \\
(.04)^{*}\end{array}$ & $\begin{array}{l}.7097 \\
(.00)^{* *}\end{array}$ & .5093 & $\begin{array}{l}.0042 \\
(.04)^{*}\end{array}$ & $\begin{array}{l}2.4056 \\
(.00)^{* *}\end{array}$ & $\begin{array}{c}.7574 \\
(.00)^{* *}\end{array}$ & .0688 & 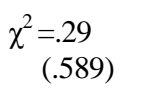 \\
\hline $\begin{array}{l}\text { Germany } \\
(\mathrm{N}=791)\end{array}$ & $\begin{array}{l}.0080 \\
(.00)^{* *}\end{array}$ & $\begin{array}{l}.6643 \\
(.00)^{* *}\end{array}$ & .3010 & $\begin{array}{l}.0080 \\
(.00)^{* *}\end{array}$ & $\begin{array}{l}1.8851 \\
(.00)^{* *}\end{array}$ & $\begin{array}{l}.5328 \\
(.00)^{* *}\end{array}$ & .0790 & $\begin{array}{l}\chi^{2}=1.39 \\
(.238)\end{array}$ \\
\hline $\begin{array}{l}\text { Hong Kong } \\
(\mathrm{N}=960)\end{array}$ & $\begin{array}{l}-.0129 \\
(.01)^{*}\end{array}$ & $\begin{array}{l}.5453 \\
(.00)^{* *}\end{array}$ & .2035 & $\begin{array}{l}-.0129 \\
(.01)^{*}\end{array}$ & $\begin{array}{l}.8858 \\
(.00)^{* *}\end{array}$ & $\begin{array}{l}.5190 \\
(.00)^{* *}\end{array}$ & .0500 & $\begin{array}{l}\chi^{2}=.03 \\
(.861)\end{array}$ \\
\hline $\begin{array}{c}\text { Japan } \\
(\mathrm{N}=1,373)\end{array}$ & $\begin{array}{c}.0038 \\
(.00)^{* *}\end{array}$ & $\begin{array}{l}.6855 \\
(.00)^{* *}\end{array}$ & .4099 & $\begin{array}{c}.0038 \\
(.00)^{* *}\end{array}$ & $\begin{array}{l}3.907 \\
(.00)^{* *}\end{array}$ & $\begin{array}{c}.4259 \\
(.00)^{* *}\end{array}$ & .1468 & $\begin{array}{c}\chi^{2}=20.30 \\
(.000)^{* *}\end{array}$ \\
\hline $\begin{array}{l}\text { Malaysia } \\
(\mathrm{N}=895)\end{array}$ & $\begin{array}{c}-.0088 \\
(.42)\end{array}$ & $\begin{array}{l}.3684 \\
(.00)^{* *}\end{array}$ & .1271 & $\begin{array}{c}-.0088 \\
(.42)\end{array}$ & $\begin{array}{l}.2262 \\
(.00)^{* *}\end{array}$ & $\begin{array}{c}-.3050 \\
(.32)\end{array}$ & .0221 & $\begin{array}{c}\chi^{2}=4.87 \\
(.027)^{*}\end{array}$ \\
\hline $\begin{array}{l}\text { United Kingdom } \\
\qquad(\mathrm{N}=5,061)\end{array}$ & $\begin{array}{l}.0065 \\
(.07)^{*}\end{array}$ & $\begin{array}{l}.5425 \\
(.00)^{* *}\end{array}$ & .1594 & $\begin{array}{l}.0065 \\
(.07)^{*}\end{array}$ & $\begin{array}{l}.2349 \\
(.00)^{* *}\end{array}$ & $\begin{array}{l}.5599 \\
(.00)^{* *}\end{array}$ & .0127 & $\begin{array}{l}\chi^{2}=.01 \\
(.908)\end{array}$ \\
\hline $\begin{array}{l}\text { United States } \\
(\mathrm{N}=18,298)\end{array}$ & $\begin{array}{l}-.0185 \\
(.00)^{* *}\end{array}$ & $\begin{array}{l}.6427 \\
(.00)^{* *}\end{array}$ & .4531 & $\begin{array}{l}-.0185 \\
(.00)^{* *}\end{array}$ & $\begin{array}{l}.2444 \\
(.00)^{* *}\end{array}$ & $\begin{array}{c}.5370 \\
(.00)^{* *}\end{array}$ & .0124 & $\begin{array}{c}\chi^{2}=4.91 \\
(.027)^{*}\end{array}$ \\
\hline
\end{tabular}

$$
\mathrm{AR}_{\mathrm{it}}=\beta_{1}\left(\mathrm{X}_{\mathrm{it}}-\alpha-\beta_{2} \mathrm{X}_{\mathrm{i}, \mathrm{t}-1}\right)+\mu_{\mathrm{it}}
$$

$X$ = annual accounting income before extraordinary items and discontinued operations, scaled by average total assets.

$A R=$ abnormal returns calculated by subtracting the mean return for each size quintile (measured by market capitalization) for each year from the realized return

$\mathrm{N}=$ the number of observations in each regression.

The $t$-statistics are shown parenthetically.

$* * /(*)$ Indicates significance for $\mathrm{p}$-values $<.01 /(<.10)$. 
The results of this test are shown in Table 2. The coefficients for the prior year's earnings are significant in both equations for all countries except Malaysia. The adjusted $\mathrm{R}^{2}$ of the second simultaneous equation, however, is much lower than for the first. For Canada, France, Germany, Hong Kong, and the UK, Wald test results (reported in the last column of Table 2) indicate that there is no evidence of a significant difference between the prior year's earnings coefficients in the two equations. This result is consistent with the market's efficient use of the total earnings information to predict the following year's earnings. On the other hand, there is a significant difference between the coefficients for the Japanese, the Malaysian, and the US data, providing evidence that from 1995 through 1999, stock markets did not efficiently value Japanese, Malaysian, or US firms' equity shares with regard to total earning persistence. For the US companies, this result is contrary to that reported by Sloan (1996). We believe that this difference may be due to the fact that Sloan's data was limited to NYSE and AMX firms, while our US data set includes a large number of NASDAQ and OTC companies. The different time periods studied may also be a factor. In summary, the second hypothesis, that investors use earnings persistence information, is supported for five of the countries, but must be rejected for Japan, Malaysia, and the US.

The second system includes one equation with earnings regressed on the previous year's cash flows and accruals, as in equation [8], and one equation with abnormal returns regressed on an expression of unexpected earnings which incorporates the relationship between current earnings and the previous year's cash flows and accruals. Although more mathematically complex than ordinary least squares regression, these systems of simultaneous equations employ a less restrictive expectations model than the random walk. This second system [10] allows for the possibility that investors might not fully discriminate between the different components of earnings.

The system of two equations shown below is used to test whether the market accurately weights the two components of earnings.

$$
\begin{gathered}
X_{i t}=\alpha+\beta_{1} C F_{i, t-1}+\beta_{2} N C F_{i, t-1}+\varepsilon_{i t} \\
A R_{i t}=\beta_{3}\left(X_{i t}-\alpha-\beta_{4} C F_{i, t-1}-\beta_{5} N C F_{i, t-1}\right)+\mu_{i t}
\end{gathered}
$$

Again, the intercept term of the forecast is held constant between the two equations and the coefficients on the variables used for the forecast are allowed to vary. This method allows us to compare the coefficients to determine whether the abnormal return is based on an accurate weighting of the forecasting variables. If investors are using the forecasting information, there should be no significant difference between $\boldsymbol{\beta}_{1}$ and $\boldsymbol{\beta}_{4}$ or between $\boldsymbol{\beta}_{2}$ and $\boldsymbol{\beta}_{5}$. Moreover, we should see the same relative values put on cash flows and accruals as are evidenced in the first equation, so $\boldsymbol{\beta}_{\boldsymbol{4}}$ should be significantly different from $\boldsymbol{\beta}_{5}$, with the same relative weighting as we see in the first equation between $\boldsymbol{\beta}_{\boldsymbol{1}}$ and $\boldsymbol{\beta}_{2}$.

The results of this test are presented in Table 3, Panels A and B. In almost all cases (except Malaysia), the variables in the second equation retain their significance. The adjusted $R^{2}$ of the second simultaneous equation is again much lower than for the first. As shown in Table 3, Panel B, $\boldsymbol{\beta}_{1}$ is significantly different from $\boldsymbol{\beta}_{2}$ for all eight countries. That is, for all countries there is a significant difference between the coefficients for cash flows and accruals, consistent with the results for the first hypothesis. Yet only for Canada are these coefficients significantly different in the second, or the market valuation, equation (the test for whether $\boldsymbol{\beta}_{4}$ is equal to $\boldsymbol{\beta}_{5}$.) In addition, for Canada, no significant difference exists between the cash flow coefficients in the two equations $\left(\boldsymbol{\beta}_{1}\right.$ and $\left.\boldsymbol{\beta}_{4}\right)$ or between the two corresponding accrual coefficients $\left(\boldsymbol{\beta}_{2}\right.$ and $\left.\boldsymbol{\beta}_{5}\right)$. Thus, this test provides evidence that for the Canadian firms, stock market pricing for the period from 1995 through 1999 efficiently impounded the relative persistence of the cash flow and accrual components of earnings.

For both Germany and the UK, there is no significant difference between the cash flow coefficients or between the accrual coefficients from equation to equation. While these results support investors' use of the relative persistence of the cash flow and accrual components, it is undermined by the fact that the coefficients in the second equation are not significantly different. Overall, there is much weaker evidence of market efficiency for German and UK firms than there is for Canadian firms in this time period. 
Table 3: Panel A

Simultaneous Regression of Earnings on the Cash Flow and Accrual Components of Prior Year's Earnings and of Abnormal Returns on a Measure of Unexpected Earnings Based on the Difference Between Earnings and the Cash Flow and Accrual Components of Prior Year's Earnings

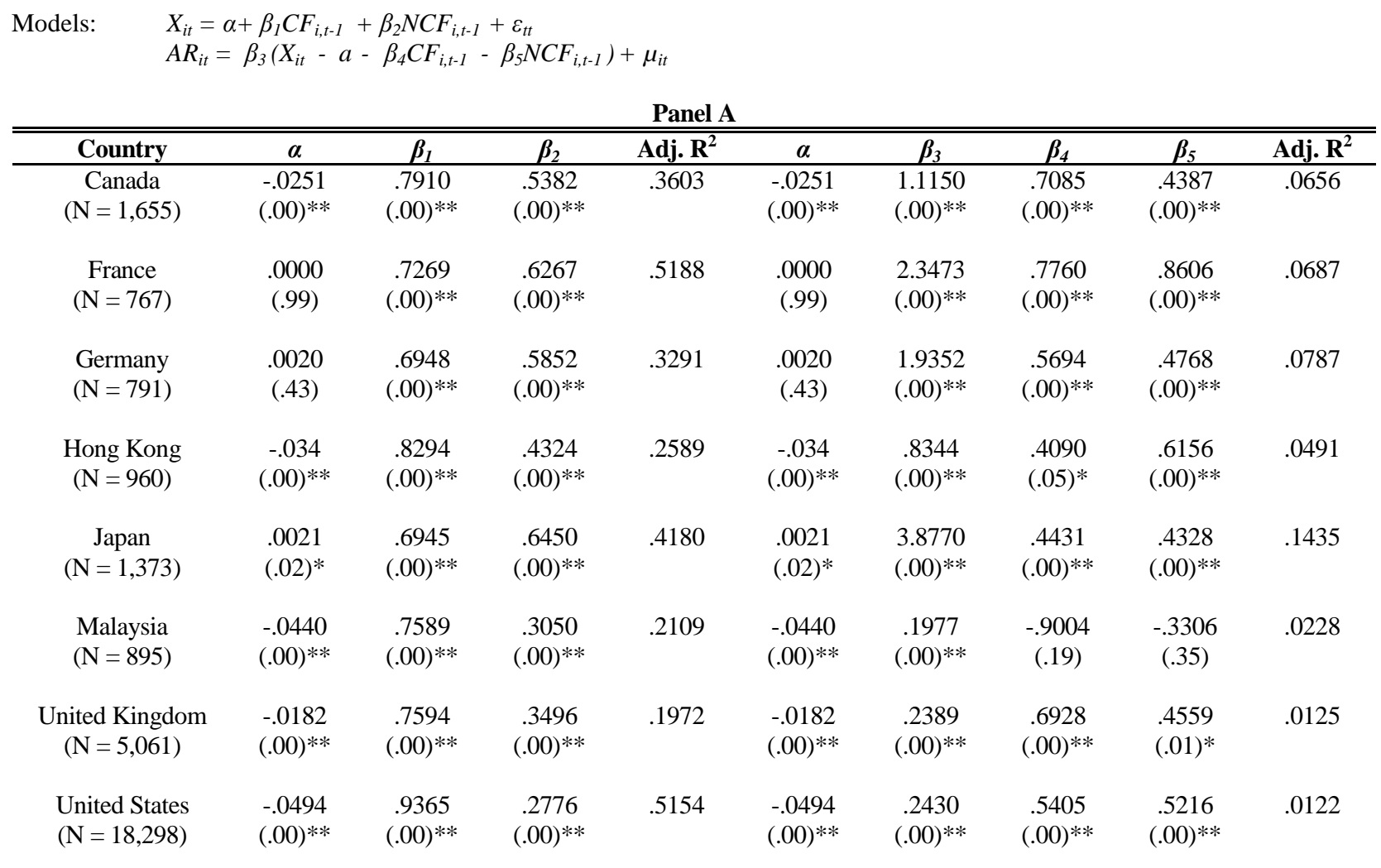

$X$ = annual accounting income before extraordinary items and discontinued operations, scaled by average total assets.

$C F=$ cash flows from operating activities reported on the Cash Flow Statement, scaled by average total assets.

$N C F=$ non-cash flows, or accruals, computed as reported annual accounting income before extraordinary items and discontinued operations less cash flows from operating activities reported on the Cash Flow Statement, scaled by average total assets.

$A R=$ abnormal returns calculated by subtracting the mean return for each size quintile (measured by market capitalization) for each year from the realized return

$\mathrm{N}=$ the number of observations in each regression.

The $t$-statistics are shown parenthetically.

$* * /(*)$ Indicates significance for $\mathrm{p}$-values $<.01 /(<.10)$.

For Japan, Malaysia and the US, there is a significant difference between both the cash flow coefficients and the accrual coefficients. For the US data set, the results are consistent with the market undervaluing the persistence of cash flows and overvaluing that of accruals. For the Japanese and the Malaysian data sets, both components are undervalued. For France and Hong Kong, one set of the corresponding coefficients is significantly different and the other is not. Despite the variation in the results, they all indicate that stock market pricing for French, Hong Kong, Japanese, Malaysian, and US companies is not efficient regarding the persistence of cash flows and accruals, which is consistent with investors not using this information. This result is consistent with Sloan's (1996) findings for cash flows in the US for the 1962 through 1991 time period. In summary, the third hypothesis is strongly supported for Canada, and there is some evidence of support for both Germany and the UK, but it must be rejected for Hong Kong, Japan, Malaysia, and the US. 
Table 3: Panel B

Comparison of Coefficients in the Simultaneous Regression of Earnings on the Cash Flow and Accrual Components of Prior Year's Earnings and of Abnormal Returns on a Measure of Unexpected Earnings Based on the Difference Between Earnings and the Cash Flow and Accrual Components of Prior Year's Earnings

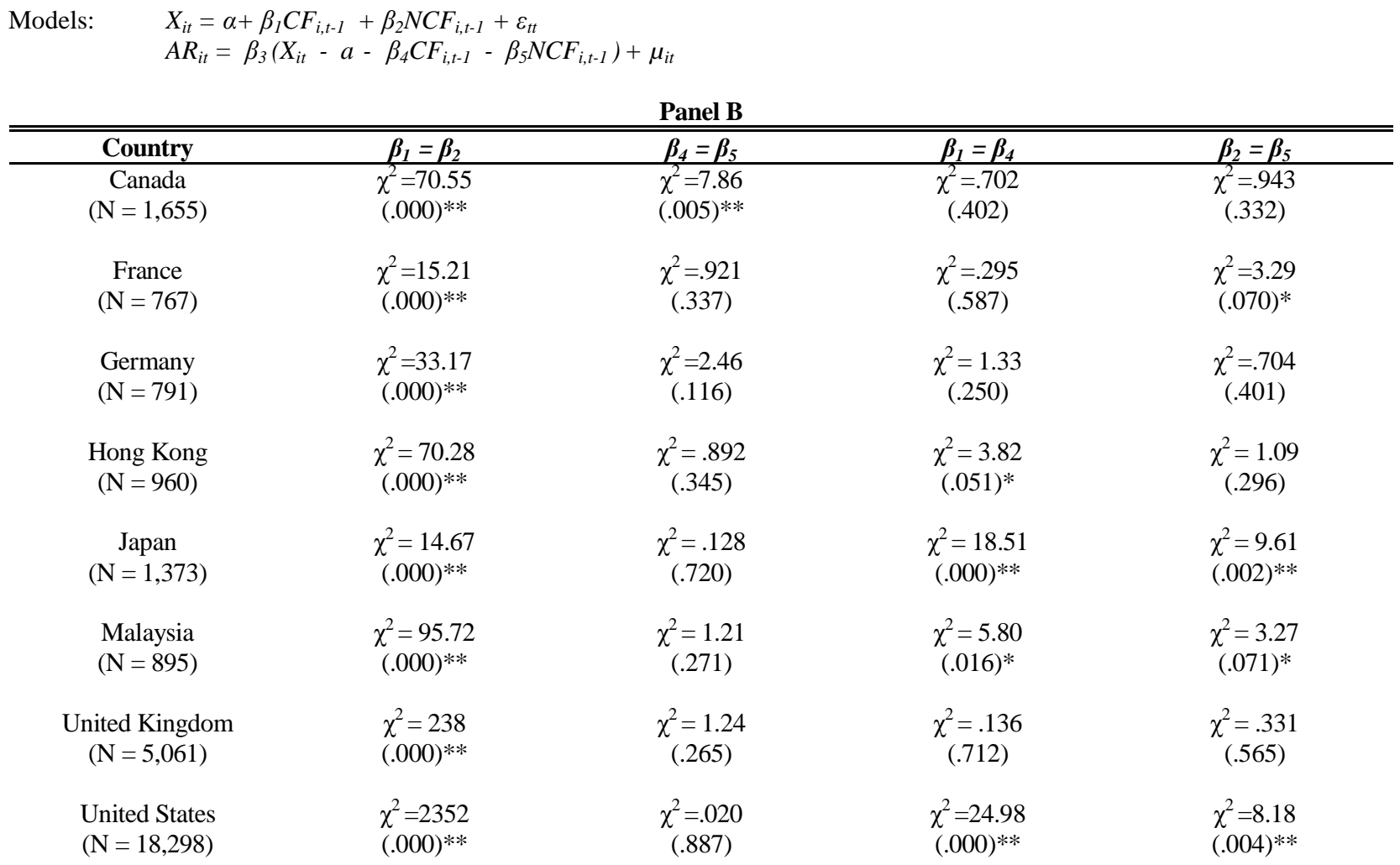

$X=$ annual accounting income before extraordinary items and discontinued operations, scaled by average total assets.

$C F=$ cash flows from operating activities reported on the Cash Flow Statement, scaled by average total assets.

$N C F=$ non-cash flows, or accruals, computed as reported annual accounting income before extraordinary items and discontinued operations less cash flows from operating activities reported on the Cash Flow Statement, scaled by average total assets.

$A R=$ abnormal returns calculated by subtracting the mean return for each size quintile (measured by market capitalization) for each year from the realized return

$\mathrm{N}=$ the number of observations in each regression.

The $t$-statistics are shown parenthetically.

$* * /(*)$ Indicates significance for $\mathrm{p}$-values $<.01 /(<.10)$.

\section{CONCLUSIONS}

Our findings demonstrate internationally that the cash flow and accrual components of earnings are both significant in predicting future earnings and that the cash flow component is significantly more persistent. This relationship holds for firms from all of the eight countries. At the same time, our results from tests using Mishkin's (1983) framework provide mixed international support for market efficiency with regard to the use of cash flow and accrual information to forecast earnings for the 1995 through 1999 time period. The results for Canada, and to a lesser extent for Germany and the UK, document that for firms in these countries, stock market pricing may efficiently reflect the relative persistence of cash flows and accruals. On the other hand, despite the change in cash flow data availability, there is no evidence that market pricing in the US, France, Hong Kong, Japan and Malaysia takes account of the relative earnings persistence of cash flows and accruals. 
Our tests were limited by the availability of data. From our database, we selected only firms with reported cash flows - which required extensive elimination. In future years, the availability of this data will increase as firms adopt the new standards requiring cash flow reporting. Further, our choice of countries was not random. On the one hand, we wanted to select countries for this initial study from accounting systems having different bases. On the other hand, we needed to select countries with sufficient data in our database. Having too small a sample puts it at a disadvantage with regard to achieving statistical significance for the coefficients in the regression models. Hence, we selected the Pacific-basin countries (Hong Kong and Malaysia) not only for geographic and cultural difference, but because of data availability. We intend to extend this research to include other countries as more data becomes available. We also intend to investigate whether the international stock markets impound the information differently for firms in different industries (e.g., manufacturing, retail, service, transportation) and whether there are differences among stock exchanges (as we believe for our US data) or for firms that are cross-listed.

By extending the work of Sloan to an international context, this research adds to the understanding of the capital market effect of accounting diversity and to the relative efficiencies of international securities markets. It also sheds light on the question of whether the increased availability of cash flow information has had an impact on stock market valuation of cash flows and accruals, which should prove helpful for accounting standard-setting bodies.

\section{REFERENCES}

1. American Accounting Association. (1977). A morphology for comparative accounting systems. The Accounting Review, 52 (Supplement), 99.

2. Ball, R. \& Brown, P. (1968). An empirical evaluation of accounting income numbers. Journal of Accounting Research, 6, 159-178.

3. - -------- \& Watts, R. (1972). Some time series properties of accounting income numbers. Journal of Finance, 27, 663-681.

4. Bartov, E., Goldberg, S. \& Kim, M. (1997). The valuation-relevance of earnings and cash flows: an international perspective. Working paper, New York University.

5. Beaver, W. (1970). The time-series behavior of earnings variables. Journal of Accounting Research, 8 (Supplement), 62-99.

6. $\quad$----ors Accounting and Economics 2, 3-28.

7. Bernard, V. \& Thomas, J. (1990). Evidence that stock prices do not fully reflect the implications of current earnings for future earnings. Journal of Accounting and Economics, 13, 305-340.

8. Brigham, E. F., Gapenski, L. C. \& Ehrhardt, M. C. (1999). Financial Management, Theory \& Practice $\left(9^{\text {th }}\right.$ ed). Orlando, FL: Harcourt, Inc., 332-349.

9. Collins, D. \& Kothari, S. (1989). An analysis of intertemporal and cross-sectional determinants of earnings response coefficients. Journal of Accounting and Economics, 11, 143-181.

10. Dechow, P. M. (1994). Accounting earnings and cash flows as measures of firm performance, the role of accounting accruals. Journal of Accounting and Economics, 18 (January), 3-42.

11. Financial Accounting Standards Board. (1978). Statement of Accounting Concepts No. 1, Objectives of Financial Reporting by Business Enterprises. Stamford, CT: FASB.

12. $\quad$---of (1987). Statement of Accounting Standards No. 95, Statement of Cash Flows. Stamford, CT: FASB.

13. Mishkin, F. (1983). A Rational Expectations Approach to Macroeconometrics, Testing Policy Ineffectiveness and Efficient-Markets Models. Chicago, IL: The University of Chicago Press.

14. Sloan, R. (1996). Do stock prices fully reflect information in accruals and cash flows about future earnings? The Accounting Review, 71, 289-315.

15. Watts, R. \& Leftwich, R. (1977). The time series of annual earnings. Journal of Accounting Research, 15, 253271. 